\title{
Married to Anatolian Tigers: business masculinities, relationalities, and limits to empowerment
}

\section{Selin Akyüz, Feyda Sayan-Cengiz, Aslı Çırakman \& Dilek Cindoğlu}

To cite this article: Selin Akyüz, Feyda Sayan-Cengiz, Aslı Çırakman \& Dilek Cindoğlu (2019) Married to Anatolian Tigers: business masculinities, relationalities, and limits to empowerment, Turkish Studies, 20:2, 297-321, DOI: 10.1080/14683849.2018.1524710

To link to this article: https://doi.org/10.1080/14683849.2018.1524710

曲 Published online: 26 Sep 2018.

Submit your article to this journal $๘$

ЏIII Article views: 224

Q View related articles

View Crossmark data \lceil

Citing articles: 1 View citing articles ¿ð 


\title{
Married to Anatolian Tigers: business masculinities, relationalities, and limits to empowerment
}

\author{
Selin Akyüz ${ }^{\mathrm{a}}$, Feyda Sayan-Cengiz ${ }^{\mathrm{b}}$, Aslı Çırakman ${ }^{\mathrm{c}}$ and Dilek Cindoğlu ${ }^{\mathrm{d}}$ \\ ahsan Doğramacı International Advanced Studies Centre, Bilkent University, Ankara, Turkey; \\ ${ }^{b}$ Department of Political Science and International Relations, Manisa Celal Bayar University, \\ Manisa, Turkey; 'Department of Political Science and Public Administration, Middle East

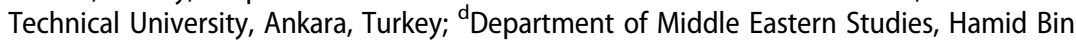 \\ Khalifa University, Doha, Qatar
}

\begin{abstract}
This paper examines business masculinities and relationalities of empowerment in the everyday life experiences of male entrepreneurs and wives of entrepreneurs in three urban centers in Turkey: Gaziantep, Konya and Izmir. We take gendered power inequalities as structural and relational, and empowerment as a complex, multifaceted process. Based on a relational understanding of gender roles, we scrutinize men's and women's decision making areas in an attempt to understand normalized and internalized patriarchal values and assumptions, as well as explicit or implicit challenges against such values. We argue that gendered experiences of entrepreneurs and women married to entrepreneurs offer a complementary analysis of nuanced empowerment strategies in the background of seemingly contradictory currents such as economic globalization, transforming masculinities, rising conservatism and reinforced gender hierarchies.
\end{abstract}

ARTICLE HISTORY Received 18 January 2018; Accepted 17 August 2018

KEYWORDS Female empowerment; masculinities; entrepreneurship; Turkey; Anatolian Tigers

\section{Introduction}

Empowerment marks a process. Reading empowerment through a gender lens requires a multi-level analysis to reveal the embedded networks, discourses, practices and institutions to which gendered identities are implicitly or explicitly subjected. As the term encapsulates the notion of power, it also entails all the normalized and internalized hierarchies that subordinate and/ or dominate. In line with Kabeer's trivet, resources, agency and achievements are significant dimensions with which to analyze female empowerment as they offer analytical room not only to juxtapose quantifiable 'gains' but also to evaluate the process of how empowerment aligns itself with social, cultural, 
economic and political contexts. Therefore, it is important to define the local parameter within which empowerment occurs, namely to contextualize it.

Processual approaches to empowerment have taken a critical stance against quantifiable global developmental goals designed to apply across countries. The criticisms point out that globalized and quantitative approaches to empowerment overlook local specificities of power relations and processual struggles to change them. ${ }^{1}$ Qualitative analysis of different stories of empowerment not only reveals choices, negotiations and subtle strategies, but also helps contextualize them. The literature also points out the significance of looking into intra-household relations in order to understand how broader structural constraints intersect with internalized forms of power and inequality. ${ }^{2}$ In line with this literature, our objective is to question gendered power inequalities and possibilities for empowerment in intra-household relations with a view to the relationality of gender constructs through an approach that is sensitive to the social, cultural, political and economic context. Investigated through the main questions and concepts of the empowerment framework, intra-household relations in Turkey have the potential to demonstrate how gendered power relations are negotiated and exercised not only at the level of close relationships but also at community and individual levels.

Reading the gender regime of Turkey, a country in the "classical belt of patriarchy" in Kandiyoti's words, has never been an easy task. ${ }^{3}$ Nurdan Gürbilek aptly defines Turkey as the "(...) [1] and of people proud that their Republic recognized the legal rights of women as its founding, but who feel constantly threatened by femininity." 4 Throughout its experience with modernization, the country found itself encircled by conceptualizations and discussions of cliché dichotomies such as East/West; traditional/modern; Islamist/secular. These dichotomous conceptualizations have been reflected in the discussions of patriarchy and gender hierarchy, limiting a comprehensive analysis of these phenomena. In the contemporary context, Turkey represents a case where gender inequalities are reinforced by both patriarchal structures, and by new and constantly forming combinations of neoliberal and neoconservative rationalities. As it has been well documented in previous research, welfare and employment policies of neoliberal capitalism intersect with neoconservative conceptualizations of the private sphere and reinforce the attribution of traditional gender roles for women as mothers and caregivers. ${ }^{5}$ It is important to investigate the everyday and intra-household reflections of the ruling Justice and Development Party's (Adalet ve Kalkınma Partisi, AKP) family-centered policies, because they help us trace how the potent change that has taken place in Turkey since 1980 introduced a new political language about Islam, modernity, and conservatism and shaped and influenced gender relations. Those reflections also offer a fertile analytical room to deconstruct the resulting "religio-conservative gender climate."6 
In this framework, this study attempts to analyse the everyday life experiences of male entrepreneurs and women who are married to entrepreneurs, living in three urban centers in Turkey: Gaziantep, Konya (centers of Anatolian conservative capital, popularly referred to as "Anatolian Tigers") and İzmir (a city that is not considered 'conservative') through a framework of female empowerment. Is it possible to argue that women are empowered in upper middle class entrepreneurial families of Anatolia vis-a-vis transforming local business masculinities? To what extent do the decision-making processes within intra-household relations reflect substantial female empowerment? To what extent do they reflect an internalization and reinforcement of traditional gender roles and patriarchal assumptions which limit women to decision making in the domestic realm? What are the explicit and implicit challenges against these roles and assumptions?

In order to answer these questions, we first define the context of transforming business masculinities among "Anatolian Tigers". We then proceed with a discussion on the concept of female empowerment, which delves into both methodological questions of how to account for empowerment, and theoretical questions of what substantial female empowerment should entail, with a particular focus on findings of previous studies on women's empowerment in Turkey. The paper then goes on to delineate the methodological approach and methods of the research and analyze the narratives of both men and women from entrepreneurial families with regard to intra-household relations and decision-making areas. This section looks into men's narratives on the gendered sphere of public/business and their perceptions of 'traditional' masculine and feminine roles in the household as well as women's narratives on their gendered roles in the private realm and how they position themselves in decision-making processes. The final part will conclude with the overall analysis on nuances of empowerment that this research uncovers. Our analysis suggests that there are transformations in entrepreneurial masculinities that reflect upon intra-household gender relations in Turkey; however, this does not necessarily correspond to strategic, long-term transformations that challenge gender hierarchies to the advantage of women.

\section{"Anatolian Tigers" and entrepreneurial masculinities}

Deconstructing the interplay between a macro socio-political atmosphere and micro strategies of spouses from the "Muslim bourgeoisie" is important in order to map different areas of power." A gendered analysis of "Anatolian Tigers" also necessitates a discussion on entrepreneurship and gender. The gendered entrepreneurial discourse has generally been discussed with reference to the dominant discourse of the separate spheres. ${ }^{8}$ Some studies have also discussed how entrepreneurship has been equated with the masculine. 9 Upon the understanding that gender is based on performances continuously 
produced through everyday practices and social interactions, there are some studies that question how enterprising men reproduce an identity they deem to be hegemonic in their own lives. ${ }^{10}$ Hence, to have a more nuanced understanding on how masculinities and entrepreneurship are culturally reproduced, there is a need to focus on how this identity is experienced in the lives of men. The ways in which masculinities are performed/learned/constructed are important in the framework of doing/accomplishing entrepreneurial masculinities. Looking into both men's and women's narratives through a qualitative approach with a view to female empowerment enables us to understand the parameters of discussing female empowerment in relation to entrepreneurial masculinities.

At the macro level, the transnational businessmen masculinity hypothesis of Connell ${ }^{11}$ suggests that global markets and transnational corporations provide the setting for a transformed pattern of business masculinity. Towards the end of the 1990s, a globalized economy and neoliberal politics have heightened insecurity and challenged older patterns of business in the world and in Turkey; a country which experienced an "accelerated liberalization" with a relatively "new business community" in search for new markets. ${ }^{12}$ Filiztekin and Tunalı's questioning of whether Anatolian Tigers can be considered as evidence for 'Turkey's entrepreneurs' ability to respond to new opportunities in an increasingly globalized market"13 coincides with the argumentations on 'new world order masculinity'.

In this framework, whether this so called "new and different generation" transgresses old forms of masculinities emerges as an important question of inquiry as well. ${ }^{14}$ As a potential transformation in the construction of masculinities that effect women's empowerment, reading the process of "Islamification", in Hoşgör's words, through a gender lens becomes much more imperative. ${ }^{15}$ This process of Islamification made it possible for pious, regional actors to build wealth and invest in social and political networks where they were previously sidelined. ${ }^{16}$ On the other hand, "neo-conservative familialism"17 and the existence of woman/wife/mother in the private, and $\mathrm{man} / \mathrm{husband} /$ father in the public realm and the related discursive practices have reproduced and reinforced gender hierarchies. Hence, a nuanced reading of female empowerment in this context also helps us look into a context that is imbued with seemingly contradictory currents such as economic globalization and transforming masculinities on the one hand; rising conservatism and reinforced gender hierarchies on the other hand.

\section{Empowerment: conceptual background}

The concept of empowerment is a widely contested one. The scholarly discussion on female empowerment revolves around conceptual questions over what "empowerment" entails, and the concomitant methodological 
discussions of how researchers can account for it. It has been frequently argued that those approaches which seek to quantify female empowerment tend to focus on access to resources and measurable outcomes at the cost of overlooking the distribution of power, gendered power inequalities and the transformations that take place in these realms. ${ }^{18}$ Batliwala $^{19}$ and Cornwall ${ }^{20}$ argue that empowerment projects focusing on quantifiable gains leave existing power inequalities untouched and hence empty "empowerment" of its radical potential.

Following this vein, this study approaches the concept of empowerment through a processual understanding of social change and employs a qualitative approach which gives weight to understanding various strategies and discourses adopted by women that help us gain insight to and develop a nuanced understanding of women's empowerment. We also adopt a relational and contextual approach to empowerment, which requires an understanding of women's roles with respect to men's roles and gendered expectations in their local context.

In the conceptual discussion on what constitutes empowerment, one central point of debate concerns empowerment in non-Western contexts. The assumption of using Western capitalism-based values as the reference points with which to understand women's empowerment, has previously been criticized by researchers. Abu Lughod ${ }^{21}$ and Bulbeck ${ }^{22}$, among others, point out that measuring empowerment on the base of Western, middle class values such as individualism, individual rights, separation from family, or consumerism overlooks women's local struggles that can unfold in a multitude of ways.

Researchers who defend a localized approach to empowerment underline the significance of "subtle strategies"23 for women's empowerment which refers to "any strategies that attempt to achieve profound, positive changes in women's lives without stirring up wide scale dissent." ${ }^{24}$ Similarly, Kabeer highlights women's "backstage influence" i.e. informal, subtle models of decision making by which women make actual decisions without threatening men's public image. ${ }^{25}$ She contends that decision making practices are not always confrontational, and previous research has found much evidence, especially from the context of South Asia, regarding transformations of power relations through "informal decision-making" and "private forms of empowerment." ${ }^{26}$ Scheyvens ${ }^{27}$ also gives examples from cases where women take chances to transform internalized power structures through non-confrontational ways, such as using traditional women-only gatherings as a platform for empowerment.

Looking into "subtle strategies" is indeed useful in terms of understanding local struggles of women which are not necessarily articulated in a liberal feminist language of empowerment and emancipation. Subtle strategies may help women gain self-confidence and help elevate their self-perception as strong 
and capable, which has been underlined as among the essential conditions that prepare the ground for women's empowerment. ${ }^{28}$ They may also pave the way for a profound questioning of gendered power relations, as Scheyvens $^{29}$ suggests. Yet, how subtle strategies work in the long term, and whether there may be a risk of reproducing gendered power inequalities should be carefully examined. Borrowing Molyneux's ${ }^{30}$ distinction between strategic and practical gender interests, it is indeed important to ask whether such subtle strategies serve "strategic gender interests", that is, long term transformations that challenge gender inequalities, or whether they result in practical gender interests which correspond to "a response to an immediate perceived need." 31

Feminist approaches to empowerment that employ the Gender and Development framework of analysis for understanding women's empowerment, focusing on the structural and contextual aspects of gendered power inequalities $^{32}$, provide us with vantage points to question and scrutinize which processes lead to the realization of women's strategic gender interests. Developing individual confidence ${ }^{33}$ and self- perception as strong and capable ${ }^{34}$ is argued to be an essential building block for empowerment in terms of "undoing the effects of internalized oppression." 35 However, empowerment at the individual level is not sufficient in itself for long term transformative critical engagement with social and cultural norms that normalize gendered inequalities. ${ }^{36}$

When it comes to assessing whether enhanced individual understanding of self-worth and confidence, in other words cognitive and psychological dimensions $^{37}$ of feeling stronger, can develop into transformative change, the literature points out the significance of developing collective consciousness ${ }^{38}$ that brings women into cooperation, changing "the way they come to think of themselves and their entitlements not only as individuals but also as people who share something in common." ${ }^{39}$ Batliwala ${ }^{40}$ underlines that women's empowerment is essentially a socio-political process and requires developing ideological and institutional challenges against prevailing structures of power. She also argues that when the socio-political dimension is neglected, the meaning of empowerment shifts towards a neoliberal conceptualization limited to the individual domain, hinting at the achievement of more individual power and status. To put it more clearly, this thread of literature puts the emphasis on critical collective consciousness about gendered inequalities and struggle against power structures in which they are nested.

Another vantage point to assess whether substantial, transformative empowerment is taking place, would be to look into the level of close relationships ${ }^{41}$ and intra-household power relations ${ }^{42}$ and discuss the extent to which women can take strategic decisions in their closest relationships. Naila Kabeer's ground-breaking work has located the concepts of "choice" and "decision making agency" as central concepts to empowerment research ${ }^{43}$, with particular sensitivity to intra-household relations and decision making 
in the household. Kabeer notably argues that empowerment is, in its essence, about acquiring the ability to make strategic life choices. ${ }^{44}$ In her account, three interrelated dimensions are necessary in order to acquire this ability: Resources, agency and outcomes. Having access to resources and possessing decision making agency are enabling factors for empowerment. Decision making agency does not refer simply to exercising choices but also to making purposeful decisions which transform gendered power relations. ${ }^{45}$ In order to account for decision making agency, Kabeer suggests that one should focus on the processes of how decisions are taken, what role women play in these processes, and whether those decisions have significance for women's lives. She recommends an approach that is sensitive to the hierarchy between decision making areas:

More commonly we find a hierarchy of decision making responsibilities recognized by the family and community, which reserves certain key areas of decision making for men in their capacity as household heads while assigning others to women in their capacity as mothers, wives, daughters and so on. ${ }^{46}$

In the framework of relationality, Kabeer's qualitative study ${ }^{47}$ on how gainful employment affects women's empowerment in urban Bangladesh reveals the importance of looking deeply into intra-household relations. This study uncovers that even though waged employment has enlarged women's area of decision making, there are still areas of "non-decision making," such as domestic division of labor, which work to the disadvantage of women. Non-decision making areas are those that are not even discussed or contested. They reflect cultural norms and values that are taken for granted.

At this point, we need to acknowledge that looking into intra-household power relations and trying to understand decision making processes in the household through an empowerment framework, necessitates a nuanced inquiry. There are at least two significant challenges to be met during such an inquiry: Firstly, researchers need to be aware of the hierarchy among decision making areas, even when there is improvement in women's conditions in terms of decision making. Secondly, it is crucial that empowerment research remain sensitive to the forms of negotiations, "patriarchal bargains," to borrow Kandiyoti's term, and the dynamic operations of patriarchal structures which, as Kabeer notes, "create gender-asymmetries in endowments, risks and constraints which penalize autonomous behavior for women but also offer them provision and protection if they remain within its parameters" ${ }^{48}$, while also acknowledging that security provided by family may be essential for survival, particularly among working class women. ${ }^{49}$

Empowerment research on Turkey which focuses on intra-household relations has generally discussed the above mentioned issues, and explicitly or implicitly dealt with questions of strategic vs. practical gender interests, and subtle strategies. Such research has usually looked into women's gainful employment ${ }^{50}$ and discussed women's empowerment in intra-household relations. ${ }^{51}$ 
The studies which analyse women's empowerment by investigating intrahousehold relations have usually discussed to what extent empowerment occurs as a result of women's gainful employment. The findings of such research have more often than not provided the insight that women's work results in the advancement of practical gender interests in Molyneux's terms rather than long term transformation of gendered power relations. For example, Beşpınar ${ }^{52}$ explores women's empowerment in Turkey through work-related strategies and their intra-household negotiations of power. The focus of her research covers middle class and upper-middle class urban women as well as working women. Her findings uncover that even though class matters in determining the nuanced strategies used by women, women of different classes tend to use individual bargaining strategies to negotiate power with both their husbands and with patriarchal structures in general. These strategies may give them individual "breathing room," 53 and yet reinforce traditional gender roles. In other words, women's work related strategies reflect practical gender interests rather than strategic gender interests and do not end up in processes of collective empowerment.

Similar to Beşpınar, Bolak ${ }^{54}$ explores marital power dynamics in urban households where women are the major providers. Her approach is sensitive to a context of transformation in men's and women's responsibilities. Her research points out that the weakening of traditional ties, particularly with husbands' extended families, enables a more flexible ground for negotiations whereby women providers can extend their decision making power. ${ }^{55}$ In such a social context, men whose wives are positioned as major providers for the household have to take more domestic responsibilities, cultivating a further fertile ground for long-term transformations in marital power dynamics. This research underlines that women's empowerment is to be better understood with an approach that is sensitive to the relationality of gender roles in a context of social change.

In this framework, although there is a growing literature on empowerment in Western and non-Western contexts in general, in Turkey, in particular, there is still fertile room for discussions that remains untouched. This study contributes to empowerment literature in Turkey by looking into gender relations in the context of changing business masculinities among middle and upper middle class entrepreneurial families in Turkey, and exploring the possibilities and limits of women's empowerment in this context. As Beşpinar $^{56}$ also notes, the studies which explore women's empowerment with regard to women's labor force participation, usually focus on working class women whereas middle and upper middle-class women are under researched. Another void in the literature is the lack of studies which adopt a relational approach to empowerment and explore men's, as well as women's perceptions and assumptions about intra-household gender 
relations. When we take gendered power inequalities as structural and relational, and empowerment as a complex, multifaceted process, it becomes more important to look into how both women and men perceive and narrate their areas of decision making, as well as the relational constructs of masculinity and femininity.

In this study, we compare the attitudes, choices and decision-making practices of women, with entrepreneur men in these cities to observe how women and men position themselves in the general hierarchy of patriarchal society. Do women take such hierarchical power relations for granted? Do they negotiate? How and to what end? How do men perceive their position with respect to family, business and social life? What are men's and women's areas of decision making and socialization? To what extent do those areas reinforce social and cultural norms that perpetuate gendered inequalities in Turkey? Are there transformations that challenge those norms? How do the changing constructs of masculinity and femininity figure in terms of women's empowerment?

Not only the areas of decision making, but also areas of 'non-decision making' are significant in understanding how power operates in intra-household relations. In line with the suggestions of the literature on how to deal with empowerment conceptually and methodologically, this study is sensitive to the relationality of women's decision making areas vis-a-vis the web of social relations they inhabit, as well as to non-decision making areas which reflect unquestioned cultural norms. We found that women in our research have a relative dominance over decisions concerning household consumption, and their domestic roles are taken by men as essential to the success of the family business. They also generally reflect a sense of self-confidence and mention subtle strategies through which they influence decision making areas attributed to men. What are the possibilities and limitations of these individual strategies in terms of empowerment? How much do they transform into collective critical consciousness that question gendered inequalities?

In other words, this study follows a perspective that distinguishes between practical and strategic gender interest ${ }^{57}$, and underlines the significance of developing collective critical consciousness ${ }^{58}$ as well as challenging established decision making areas in attaining substantial empowerment.

\section{Methodology}

This study pursues certain issues we have analyzed within the context of a TUBITAK funded research project: New Capital and Conservatism: Anatolian Tigers from the Perspective of Sociology of Everyday life (113K521, 2017). Our fieldwork was realized between May 2014 and November 2016. While this paper is based on data collected in three major industrial commercial cities in Turkey: Konya, Gaziantep and Izmir, the research was conducted in four 
additional cities, namely Kayseri, Mardin, Diyarbakır, and Urfa. Throughout the field research, 95 semi-structured interviews with businessmen and 24 focus group discussions with men and women were conducted. Two focus groups in each city were designed to be made with male entrepreneurs and women who have entrepreneur husbands. We were able to reach our respondents through snow-ball sampling. We paid close attention to involving men from different age group and sectors like automotive, telecommunication, food, construction and appliances. The main topics that were covered during the interviews included detailed stories of their life history as entrepreneurs and their current business lives, in addition to the way they established their families, and the division of roles within the household and in their social life.

Our broader aim in the course of this research project was to study the gender practices of conservative entrepreneurs in certain Anatolian industrial and commercial cities. In general, we focused on conservative masculinities with reference to their social context of business and family ties. In this regard, we have aimed to reveal the asymmetrical hierarchical power relations among the Anatolian Tigers and grasp the image of conservative man within the context of their families and social networks. In parallel to the broader purpose of the research, for this specific work, we have used 51 in-depth interviews mainly with businessmen of small businesses and two focus group discussions in each of three cities, one with male entrepreneurs and the other with women married to entrepreneurs. For this work, we selected three, out of seven cities, and each had its own representative task: the cities of Konya and Gaziantep, known as two leading Islamic conservative business capitals and Izmir, as the leading secular modernist commercial center of Turkey rendered crucial and intriguing data to explore women's empowerment. Methodologically, we have placed an emphasis on the relationality of women's decision-making areas vis a vis the web of social relations and changing constructions of masculinities and femininities. The interviews enabled us to read different nuances of an ideal existence for men in the business realm and women in the household, helping us delve into a fertile field for the discussion of women's empowerment.

\section{"Business" as a masculine area}

To start with, the findings of the in-depth interviews and focus groups with male entrepreneurs and women married to male entrepreneurs in Gaziantep point out that not only men but also women almost unquestioningly accept business and entrepreneurship as a masculine area. Their narratives reflect a conceptualization of marriage, children, and women's role in taking care of the family as an integrated and complementary part of a successful business. Male respondents usually explained how they needed to be 
outside of the house most of the time -if not out of the city, or the country- to make their businesses flourish, and how they absolutely needed their wives to be in charge of the household and the children. A male entrepreneur who owns a local sausage factory put it as follows:

"Now a wife's duty is to raise children well and take care of them. What we do as businessmen is work almost like a superhuman. There is not a place in Turkey that I have not visited to boost sales. For example, I leave Antep, travel across the country for 15 days. How can I take responsibility for the children? That job belonged totally to my wife of course." (Bilal, entrepreneurs' focus group, Gaziantep)

Another entrepreneur who owns a home appliances store in a luxurious neighborhood of Gaziantep told us how he had warned his wife about his working conditions from the start:

"This store is open from 8 am to 8 pm, including Sundays. The store has to be open all day, retail work requires this. And the consumer wants to see me, the boss. I have to be here. My wife has no right to be angry because I told her from the very beginning." (Ali, in-depth interview, Gaziantep)

Similarly, Emre, a single businessman from the industrial zones of Konya described the ideal wife during the interview as: "My wife has to realize that she should not interfere with my business trips or time spent away from home. I work hard so she should look after children. I will earn and she will spend the money!"

In contrast to these views, women who were married to male entrepreneurs complained at length about the demanding schedules and the absence of their husbands. However, the idea that it was the wife's duty to support the entrepreneur husband's schedule by taking care of the house and the children as long as the husband earned well and provided for the family, was unquestioned.

It was interesting to observe that, in Konya, some of the women who participated in focus group discussions, who were married to entrepreneurs, were entrepreneurs themselves. Most of these women were graduates of studies in engineering, architecture, education, agriculture or commerce. They came from families that had a history in commerce and their husbands usually own small-sized commercial enterprises. Women in Konya stated that they had high hopes in terms of having a working life in line with their education. However, they found themselves steered towards arranged marriages as soon as they graduated. Arranged marriage does not, on its own, seem to be the cause of a disappointment per se, instead it is taken for granted and for some it is taken as a compromise through which one can build a profitable partnership. In general there is conformity to the general custom of arranged marriages and from within that group of women, few express any regrets. This was one of the most highlighted "non-decision making area" which reflected the taken-for granted social and cultural norms revealed during our fieldwork. 
It was remarkable how male respondents formulated a suitable marriage as an inseparable part of a flourishing business. For example, Abdülkadir, an ambitious young entrepreneur who owns a series of stores selling luxury bathroom appliances in Gaziantep, explains how he and his brother planned their business while they were setting up goals for their business: "We set ourselves a smart goal. We said we will straighten up our business, and we will get married by 2010 at the latest" (Abdülkadir, in-depth interview, Gaziantep)

The focus group conducted in Gaziantep with male entrepreneurs witnessed a heated discussion on the prospective marriage of a young participant. Whereas the young participant said he wanted to travel and have fun before getting married, an older participant of 54 years old talked at length about why an entrepreneur should get married as soon as possible:

"-Well you should get married and have children so that you will cling on to your business. Your generation is unlucky, with the internet sales and all, it is so difficult for you.

-What does this have to do with marriage?

- If he gets married, he will be motivated by the responsibility of the household and the children. Whoever builds a family hangs on to his business" (entrepreneur's focus group, Gaziantep)

Respondents have also argued that marriage is 'good for business' because wives have a 'duty' to maintain warm relations with the women of affluent business families of Gaziantep. The specific significance of social capital in Gaziantep in terms of entrepreneurial activity has been noted before by previous research. ${ }^{59}$ Our data confirms the significance of family network and close relations with affluent families of the city. The significance of maintaining existing social relations and creating new ones attribute a special role for women, particularly the wives of male entrepreneurs.

"In this city, keeping up social relations is everything. Ladies have their duties. They have to socialize to be close to the prominent families. It is an important duty... People socialize for this aim. They even send their kids to certain schools, you know, to be close to those families". (Abdülkadir, in-depth interview, Gaziantep)

Based upon the narratives, in the eyes of entrepreneur men, marriage is a necessity. Arranged marriage is very common and welcomed. Women have to look after children and govern domestic affairs for which men do not have time or energy. In this framework, patriarchal hierarchy is taken for granted. Entrepreneur men usually identify themselves as workaholics, and they portray their wives as demanding on their time. In most narratives, family time is limited to weekends and family vacations are rare events. "I work day and night constantly. I have no time for family outings or friend visits" (Arif, Konya, in-depth interview). In fact, very limited socializing 
with family seems to be the norm. "I've missed the time when my children are growing", "my wife demands attention", "I don't have a social life", "I cannot spend enough time with my wife and children" are some of the common complaints of entrepreneur men in Konya. However, they seem very confident about their higher status in the patriarchal hierarchy. "One governor is enough for one house.", "I expect them to tidy up when I come home.", "I am not as authoritarian as my father but I have the final word on all issues", well exemplify men's stance regarding their position within the household.

In these narratives, it is possible to observe that women have designated domestic roles through which they are deemed as significant, almost essential for a successful business and family life. They are relatively autonomous in making decisions related to the management of the household and upbringing of children. Their contribution to business is formulated as maintaining a social life that supports the business relations of entrepreneur husbands. However, it does not seem possible for them to challenge what is formulated as men's obligation to keep up with business. In other words, their decisionmaking areas remain within almost rigidly defined limits. Men, on the other hand, maintain a separate and highly autonomous area that remains outside the boundaries of the household. Some of the respondents made reference to their father's explicitly authoritarian attitudes toward them as children, which covertly represents generational change in traditional gender roles. To put it more clearly, our respondents defined their fathers as distant, authoritarian and reserved, while they constructed their own fatherhood within the household as involved, democratic and emotional. However, this transformation concerns their fatherhood roles rather than overall gender roles at home, so it does not challenge gender hierarchies to the advantage of women. The narratives of entrepreneur men reveal that as long as women perform their expected roles without being too demanding on their husbands' autonomous areas, they are provided financial and social security and appreciated as successful mothers and housekeepers who maintain the well-being of the family.

\section{"Women's designated areas" in business}

When it comes to the issue of women's involvement in business, the narratives of male respondents point out that they are not necessarily against women's participation in paid work. However, there are "designated areas" which indicate where and under which conditions they wish women and therefore, also their wives and daughters to work.

"Yes, we have some female fellow workers. But I am not happy with this. It is like a Barbie doll office with them. They are gossiping, talking, crying ... In this office, there is now a single woman who works as an architect others are working for cleaning and catering." (Koray, in-depth interview, İzmir) 
"I do not need my wife to work. She can work with me if she absolutely has to

-You mean in your store?

-Sure. 10 people work for me right now. She can be my 11th employee" (Emir, focus group, Gaziantep)

Kaya, a 62 year-old businessman who owns a pistachio supply company located in the Organized Industrial Zone of Gaziantep, wanted his daughter, an undergraduate student of Psychology in a private university in Istanbul, to work as a psychologist whereas he raised his son to continue his profitable business. He was against women's involvement in the pistachio business:

"We do not speak of business at home. We do not let women get involved. I am not against working ladies. But not in this sector. A lady would need to mingle with the peasants and the middlemen. That is no good." (Kaya, in-depth interview, Gaziantep)

In parallel to Kaya, Onur, a mechanical engineer from Izmir, who owns a big shop of electronic appliances, had different plans for his son and daughter:

"My son is about to graduate and will be working with me. I will be here to help him, there is a big team. We will find a way. My daughter will be graduated in two years. She does not want to work with me. She has some entrepreneurial ideas. She wants to do some fancy stuff of organizing big weddings and events. Of course, I will give the amount that she needs and I will help her for sure but I am also sure that she would fail." (Onur, in-depth interview, Izmir)

Similar to male respondents, female respondents also regarded paid work as a contingency, as a temporary solution to resort to when there is a financial emergency:

"When my husband went bankrupt, I got into home based catalogue sales. It paid for my kid's needs and I had some pocket money.

-How about working outside home or setting up your own business?

-I did not have the courage. Actually I am a very good cook. I thought about home cooking and a catering business. But we did not have much money then and I was not bold enough" (Aysel, focus group, Gaziantep)

In their tendency to mark business as their own, masculine area, male entrepreneurs claimed that they kept their wives out of business and investment decisions:

"Business is my own sphere. It is like black and white. I do not have grey zones. It was hard for my wife at the beginning but now she is used to this system. I will not let anybody other than me into my realm in my business." (Kerim, in-depth interview, Izmir)

“-In my generation, we were not used to asking our wives' opinions. But now youngsters ask their wives. 
-I ask my wife as a courtesy. I make a decision, let's say, 80\% of a decision. I ask for her opinion. I say, "We profited the last time we bought real estate. Should I do that again?" She says "Sure, do that". (Ali, focus group, Gaziantep)

On the other hand, the narratives of female focus group participants tell a different tale. Women formulate their role in business related decision making as a 'backstage' role, in which they interrogate the decisions of their husbands, leading them in some of the decisions, without making the impression that they are 'leading'.

"-I always want to be on the safe side moneywise. I am not the kind of woman who would wait obediently for her husband to give her money. I am into details, I am all about guarantees. I ask many questions. I understand that he is struggling when he avoids answering me.

-What do you ask him?

-The classic questions. How is business? How much did you make this month? Are we able to pay the employee wages this month? Can we pay for their insurance? Can we make it through the month? Can we pay for my expenses and the kids'? Questions of this sort". (Nuray, focus group, Gaziantep)

“In 5 years' time, I want to be managing my husband's business. I want to develop the business. Actually I want to see myself in a very high position. Next to my husband." (Serpil, focus group, Gaziantep)

"I am the one who makes decisions in the household and about my husband's business. For instance, when there is an issue on the table, I am implicitly manipulating him. He does not realize it. At the end, he thinks it is his decision but it is my idea that I have imposed on him sneakingly." (Yeşim, focus group, Izmir)

Women entrepreneurs on the other hand reflected another picture; one entrepreneur woman in Konya emphasized commitment, hard work and being independent in terms of access to and command of economic resources. As one interviewee said "I am the daughter of a groceries retailer so I did not have any problems or difficulties in becoming an entrepreneur. I already knew the risks". Naciye, from Konya, who is in the printing business told us how she fixes the electronic machines though she did not have any previous experience in technical matters. "I used to go to tea parties with my mother in law when I was a housewife, now I dream about better machines." Banu, another entrepreneur women in Konya, described how she invested in a cattle farm business by negotiating with her own parents as well as her husband's parents. She invests family capital, manages the farm as she has "the commercial spirit" whereas the husband in her words "knows nothing about cattle farming, I am the dominant one. He is like a house ornament and there is nothing to do about it". Naciye who has her own printing shop claimed proudly that "I've got my own bank account" and continued "It is 
good to have your own business. I am covered with toner dust but I love it." Women entrepreneurs in Konya were self-confident and they portrayed themselves as part of a community, supported by family and parents. They emphasized that they are wives and mothers who have obligations at home, who are in the service of household duties, who are committed to both marriage and business. Although they tried to keep up with housework, it is not a priority. Selma who is in groceries retail and works as a partner with her husband said : "I used to be a very good cook but I am not interested anymore. I used to wear high heels; now as I go to work every day I don't care. I wear my sneakers everywhere now."

Decision making in terms of business or investment is a matter of consultation with family members. Investment, business and profit making are acceptable goals to pursue for these women. As long as they do not contradict or contest the general customs or rules they seem to be free and independent. In this regard being 'normal' is more valued than being 'independent'. Women emphasized the fact that they have continuously been receiving support from husbands and fathers. Clearly, they are surrounded with a safety net of family ties. In this regard, there seems to be an implicit assumption that if one conforms when one has to, then one may engage in certain independence as well.

When it comes to disagreements, women make sure to appear to conform with their husbands' decision, but also continue to insist until they get their own way. "I insist and insist, soon enough he realizes he is mistaken!" mentioned Hatice, whose husband has a jewelery business in Konya. Although she couldn't persuade her husband to work together in the jewelery shop she makes sure that she is part of the decisions concerning investment through backstage influence.

\section{Men's and women's separate areas of socialization}

Based on the narratives of participants, it can be argued that, men and women do not usually socialize together. Men explain their social activities (dinners, sometimes weekend vacations to nearby places) as an extension of their business activities in order to enhance some business relations and make new ones. They also take business related vacations abroad (e.g. to visit international fairs, customer visits) but wives are usually not welcome to join.

"We spend the weekends with family. In the weekdays, we escape from home. I go to Izmir at least once a month. I go to Istanbul every two weeks. I take a vacation abroad two of three times a year. I am 35 years old. I have been abroad 25 times. But never with my wife. They are usually men only escapades. The franchise (bayilik) system also encourages travelling abroad. They organize motivation trips. Good sales numbers may take you to St. Petersburg. It is important to be knowledgeable about foreign countries. People of Antep are open to the world, they learn quickly." (Ali, in-depth interview, Gaziantep) 
Businessmen in Konya seem eager to get away from the city for business trips and for leisure time. Serkan, a divorced young man selling household appliances to help the family business, makes sure to leave the city at least once a month. "I take salsa classes, go skiing or scuba diving". He even invests in a business outside Konya, to go to business trips. Mete, a married young coffee shop and construction business owner said "Konya is very conservative. I cannot do anything fun with my family and wife. Instead I go out with my friends to drink beer. There is a hotel bar that serves alcohol, we go there. I like gambling, luxury shopping and overseas trips which I do away from family and relatives."

The narratives of the female research participants also point out to separate socialization from their husbands. They usually spend vacations with female relatives. Sports, movies, shopping, picnics, visits to thermal spring resorts are some of the activities they engage without their husbands.

“- How is it to be married to an entrepreneur in terms of social life?

-It is definitely not good. He cannot spare any time for us, sometimes he even has to spend the weekend at work. We go to thermal springs with my sisters and children. Usually our husbands are not with us.

-Yes I also make social plans with my sisters. Our husbands are not around. But we like to be socially active. (Focus group, Gaziantep)

In Izmir, although there were some female participants who enjoyed underlining their difference - from what they usually formulated as conservative Anatolians- and proudly stating that "we are going everywhere together" or, "my husband cannot move without me", some did reluctantly mention:

"He is going with his own friends. We miss our father. He is spending time at work or at business trips. He is also very frequently traveling to France. It is like half of the year. When he returns from Paris, at the beginning I cannot easily reconcile myself to his existence. Then, later it is OK." (Ayla, focus group, Izmir)

Although the participants of research in İzmir identified themselves as 'modern', underlining their difference from the inhabitants of other cities they defined as conservative; the boundaries of socializing are still determined by taken for granted norms. Women are engaged in separate leisure time activities, usually with their children and female relatives. They complain about the limited time that their husbands spare for their families. But they do not critically scrutinize the idea that their husbands need to be away all the time because of business obligations.

It is important to note that similar to the realm of business; the realm of socialization also seems to be designated by entrepreneur men as their autonomous area. The male participants of the research narrate their leisure time activities as an integrated part of their efforts to develop their business 
relations. Those activities include not only dinners but also vacations, including international travel which is usually supported by the franchise (bayilik) system of major companies. Whereas the increasing frequency and familiarity of international travel for local businessmen hints at possibilities for transforming masculinities in a context of globalization, women do not seem to benefit much from such opportunities accorded their husbands as they get to be the ones "left behind" at home and keep up with the chores of everyday life. On the other hand, one could also argue that businessmen's separate social life also opens up a realm of possibility for their wives as well, as long as they can negotiate a relatively autonomous sphere where they can enjoy female-only leisure activities.

\section{Concluding remarks}

This study explored the gendered hierarchies among upper-middle class entrepreneurial families from three commercial cities of Turkey. The objective is to understand the possibilities and limits to empowerment for women married to entrepreneurs. The cities, which are representative of different socio-political stances within Turkey, offered an effective room for such analysis. The analysis of Konya and Gaziantep, representing two business capitals mainly populated by "pious conservative rich" ${ }^{60}$ and Izmir, the city referred as gavur - an expression referring to non-Muslim citizens who have populated the area since Ottoman Empire- provided us with an understanding that although there are some distinct patterns to each, masculinist necessities, to put it in general terms, still define the boundaries of decision-making areas. In our study of empowerment we aim to investigate to what extent gender norms and hierarchies are challenged, modified or maintained in intra-household relations. Focusing on uppermiddle class intra-household relations helped us analyze the relationality of gender norms. Comparison of men's and women's areas of decision making, non-decision making and influence on decision making showed how gender norms and hierarchy are produced and modified in everyday life practices. At the general outset, the comparison of attitudes and decision making practices of self-identified "conservative" and "modern women" did not render significant differences in terms of how women internalize the existing gender regime or position themselves in the general hierarchy of patriarchal society. It seems that women in İzmir who identify themselves as modern, share the gender climate of women in Konya and Gaziantep.

Our qualitative analysis of empowerment aimed to perceive the choices, negotiations and strategies of women in a highly gendered and masculine environment of business and patriarchal context of home. Our initial inquiries such as whether women challenge the existing gender regime, contest hierarchies or redefine patriarchal roles with more egalitarian assumptions delivered us two spheres in which we could analyze our findings. 
The first one is the sphere of business. The way business is addressed as a space by men and women provided peculiar differences of attitude. We have seen that for entrepreneur men, business is a designated space for men. Entrepreneur men usually rely on a personal success story. "I received no support from anyone" is a recurring statement of the success story of the "self-made man". Women have a limited and bounded part in that success story within their capacity as mothers or wives. Entrepreneur men are self-conscious authority figures, portraying themselves as productive, industrious and residing at the center of business life. For them, wife and children are consumptive and demanding. Generally, entrepreneur men position themselves as part of a homogenous community of a highly masculine society. Fraternal and patriarchal values are prevalent. For women on the other hand, if she is an entrepreneur business is a space partaken and enjoyed only with the material and mental support of family and relatives. For the wives business is a space for men, work and livelihood. Women do not seem to contest or challenge the power of men.

The other sphere, that is home, for the entrepreneur men, is the place where women and children reside. Entrepreneur men usually make a point to stay away from this space as it is a space for consumption, demands for socialization and care for necessities. Accordingly, women are not regarded as part of competitive power relations; they reside in private space. The entrepreneurs who participated in this research have not questioned male domination. The powerful role attributed to woman/mother/wife in the household eases the maintenance of order but man/father/husband is still perceived as the catalyst of the system by the majority of the participants. However, for women home is the platform where real negotiations and crucial decision making take place usually through backstage influence on men's decisions regarding both home and business. This is where some women see themselves as leading without seeming to lead. Home is the sphere in which women seem empowered in the backstage but it works as long as women aspire and perform their role in the gendered hierarchy of patriarchal society.

Our research has also gave us the opportunity to look into the extent to which gendered hierarchy changes when married women are also entrepreneurs in this context of "business as men's world". Entrepreneur women in the case of Konya seem to place themselves on an equal basis with their husbands in terms of business life. They have socially acceptable goals to accumulate and increase gain and profit. Furthermore, they also perform as wives and mothers who have commitments at home. Being an entrepreneur may bring personal and relational empowerment but not necessarily a change in gender norms. The social pressure to behave in a normalized way and the sole option of performing a backstage influence in decision making seems to shadow empowerment in the sense of bringing about change in established gender norms. 
The narratives of female research participants on consumption reflect a pattern that ironically empower women within the household by not undermining their traditional gender roles and instead reinforcing it. Women construct their own area of consumption. In this area, they are relatively "free" to use their power. Making the decisions for life within the household embolden her in varying aspects for different reasons. "He does not know what is going around. I am doing everything for the home"; "He cannot even choose one single thing for the house"; "It is impossible for him to buy anything for himself. He needs me." are some of the repetitive patterns of perceptions and resulting actions. At this point, the power to take decisions in the lower echelons of hierarchy of decision making areas can be read as the armament of women in a sphere where her counterparts are well equipped with the help of masculinist necessities.

Whereas women have reduced men's ultimate authority -and also responsibility, for that matter - over household decisions by anchoring themselves to their traditional gender roles and/or socio-cultural norms, there remains some area for men to have responsibility and influence in the sphere of home and as being involved fathers. The changing constructions of femininity and masculinity figured latently in women's empowerment by creating loopholes for the ways in which feminine care and masculine authority are gendered. Upper middle class wives of Anatolian tigers seem to exchange conformity to conservative gender climate with certain independence in terms of (backstage) negotiations, decision making and strategies regarding home and business. Does conformity bring empowerment is the query where we conclude our analysis.

To summarize, feminist researchers have well documented how care has been gendered in feminine and career works as a pre-requisite of masculinity. This way of argumentation has also marked the gendered analysis of the deeprooted dichotomy of separate spheres. The demarcation lines between feminine private and masculine public realms are also analyzed in depth. Especially, after the integration of the discussions around "transnational businessman masculinity" ${ }^{161}$ into the literature, it is more significant to reveal the intriguing ways in which entrepreneurial masculinities are crystallized. In this framework, this research attempted to question empowerment through a processual understanding of women's roles with respect to men's roles. The analysis of Anatolian Tigers provided a fertile room to read different areas of gendered hierarchies and its reflections on intra-household relations that mirrored "new" patterns of business masculinities. At the global level, the transformation of business masculinities and the increase of women's participation into labor markets have shaped the stepping stones of economic globalization. However, in Turkey, a new rising bourgeoisie, in line with culturally reproduced repercussions of masculinities, reproduced a safety net within the family that is propped up with the help of wives. As a response to the risks and dangers of a free market economy, the normalcy nourished by 
traditional Turkish family values and patterns of gendered relations dominates social and private life in Turkey.

\section{Notes}

1. Batliwala, "Taking the Power out of Empowerment."

2. Kabeer, "Women, Wages and Intra-Household Power Relations."

3. Kandiyoti, "Bargaining with Patriarchy."

4. Gürbilek, The New Cultural Climate in Turkey, 1.

5. Acar and Altunok, "The 'Politics of Intimate."

6. Güneş-Ayata, and Doğangün, "Gender Politics of the AKP."

7. White, Muslim Nationalism and the New Turks.

8. Ahl, "The Scientific Reproduction," and Hamilton, "The Discourse of Entrepreneurial Masculinities."

9. Bruni et.al., "Doing Gender, Doing Entrepreneurship"; Ahl and Marlow, "Exploring the Dynamics of Gender", and Giazitzoglu and Down, "Performing Entrepreneurial Masculinities."

10. Down, Narratives of Enterprise; Smith, "Masculinity, Doxa and the Institutionalisation of Entrepreneurial Identity"; Giazitzoglu and Down, "Performing Entrepreneurial Masculinities."

11. Connell, "Masculinities and Globalization."

12. Demir et al., "Anatolian Tigers or Islamic Capital."

13. Filiztekin and Tunalı, "Anatolian Tigers: Are They for Real?"

14. Demir et al., "Anatolian Tigers or Islamic Capital."

15. Hoşgör, "Islamic Capital/Anatolian Tigers."

16. White, Muslim Nationalism and the New Turks.

17. Kandiyoti, "Locating the Politics of Gender."

18. Kabeer, "Resources, Agency and Achievements"; Rowlands, "Empowerment Examined"; and Batialawa, "Taking the Power out of Empowerment."

19. Batliwala, "Taking the Power out of Empowerment."

20. Cornwall, "Women's Empowerment: What Works?"

21. Abu-Lughod, "Dialects of Women's Empowerment."

22. Bulbeck, "Feminist Theory in the Developing World."

23. Scheyvens, "Subtle Strategies for Women."

24. Ibid., 237.

25. Kabeer, "Resources, Agency and Achievements," 448.

26. Ibid., 447-8.

27. Scheyvens, "Subtle Strategies for Women."

28. Rowlands, "Empowerment Examined," and Cornwall, "Women's Empowerment: What Works?"

29. Scheyvens, "Subtle Strategies for Women."

30. Molyneux, "Mobilization without Emancipation?"

31. Ibid., 233.

32. Rowlands, "Questioning Empowerment."

33. Rowlands, "Questioning Empowerment," and Batliwala, Empowerment of Women in South Asia.

34. Cornwall, "Women's Empowerment: What Works?"

35. Rowlands, "Empowerment Examined," 103.

36. Cornwall, "Women's Empowerment: What Works?"

37. Stromquist, "The Theoretical and Practical Bases for Empowerment." 
38. Rowlands, "Empowerment Examined"; and Batialawa, "Taking the Power out of Empowerment."

39. Cornwall, "Women's Empowerment: What Works?" 346.

40. Batliwala, "Taking the Power out of Empowerment."

41. Rowlands, "Empowerment Examined."

42. Kabeer, "Women, Wages and Intra-household Power Relations."

43. Kabeer, "Resources, Agency and Achievements," and Kabeer, "Gender Equality and Women's Empowerment."

44. Kabeer, "Resources, Agency and Achievements," 435.

45. Kabeer, "Gender Equality and Women's Empowerment."

46. Kabeer, "Resources, Agency and Achievements," 435.

47. Kabeer, "Women, Wages and Intra-household Power Relations."

48. Ibid., 300 .

49. Beşpınar, "Questioning Agency and Empowerment."

50. Gündüz-Hoşgör and Smits, "Variation in Labor Market Participation," and Cindog ${ }^{\vee} l u$ and Toktas, "Empowerment and Resistance Strategies."

51. Bolak, "Marital Power Dynamics", and Sirman, "Feminism in Turkey."

52. Beşpınar, "Questioning Agency and Empowerment."

53. Ibid., 530 .

54. Bolak, "Marital Power Dynamics."

55. Ibid., 228.

56. Beşpınar, "Questioning Agency and Empowerment."

57. Molyneux, "Mobilization without Emancipation?"

58. Batliwala, "Taking the Power out of Empowerment."

59. Ayata, "Bir Yerel Sanayi," and Durakbaşa et al., "Local Notables and Businessmen."

60. Demir et al., "Anatolian Tigers or Islamic Capital”, 166.

61. Connell, "Masculinities and Globalization."

\section{Acknowledgements}

We would like to extend our special thanks to Fatima Sakarya for her help in final editing of our paper.

\section{Disclosure statement}

No potential conflict of interest was reported by the authors.

\section{Funding}

This work was supported by TUBITAK (Türkiye Bilimsel ve Teknolojik Araştırma Kurumu) 1001 Research Grant. The title of the project is "New Capital and Conservatism: Anatolian Tigers from the Perspective of Sociology of Everyday Life". The project number is $113 \mathrm{~K} 521$.

\section{Notes on contributors}

Selin Akyüz is a Research Fellow at Bilkent University's Ihsan Doğramacı International Advanced Studies Centre. She completed her doctoral studies in 2012 in 
the Department of Political Science at Bilkent University. Akyüz conducted her postdoctoral research on gendered perceptions of migration at University of Oxford from October 2014 to July 2015 as a visiting research fellow. She also participated in ethnographic research projects on gender equity, women empowerment, localities, and post-migratory experiences. Her journal publications have appeared in Turkish Studies, Women's Studies International Forum, Journal of Conflict Transformation and Security, and, Masculinities Journal. Her major research interests center on critical studies on men and masculinities, political sociology, Turkish politics, and migration.

Feyda Sayan-Cengiz is Assistant Professor of Political Science and International Relations at Manisa Celal Bayar University. She received her $\mathrm{PhD}$ in Political Science from Bilkent University in 2014. She was a visiting researcher at the Department of Anthropology at Columbia University from 2009 to 2010. She has previously worked in the Department of Media at Istanbul Bilgi University. She has published in edited books as well as journals, such as Women's Studies International Forum and New Perspectives on Turkey. Her book, Beyond Headscarf Culture in Turkey's Retail Sector was published by Palgrave Macmillan in 2016. Her research interests include political sociology, politics of gender, Islamic consumerism, social movements and media studies.

Aslı Çırakman is Associate Professor of Political Science at Middle East Technical University. She is interested in gender studies, nationalism, populism, and political thought.

Dilek Cindoğlu is Professor of Sociology at the Hamid Bin Khalifa University in Qatar. She received her PhD from the State University of New York at Buffalo. She has previously worked at Bilkent University, Mardin Artuklu University, and Abdullah Gül University. She has been a Fulbright Scholar at the University of WisconsinMadison, a Senior Fellow at St. Antony's College, Oxford, a Visiting Fellow at the Center for Gender and Sexuality at New York University, and a Visiting Senior Scholar at the The Institute for Research on Women, Gender, and Sexuality at Columbia University in New York. She has been a consultant on various research projects funded by national and international institutions. Her work has been published at several national and international academic journals and as book chapters. Her research interests include gender and sexuality, sociology of health, political sociology, sociology of work and migration.

\section{Bibliography}

Abu-Lughod, Lila. “Dialects of Women's Empowerment: The International Circuitry of the Arab Human Development Report." International Journal of Middle East Studies 41, no. 1 (2009): 83-103.

Acar, Feride, and Gülbanu Altunok. "The 'Politics of Intimate' at the Intersection of Neo-Liberalism and Neo-Conservatism in Contemporary Turkey." Women's Studies International Forum 41, no. 1 (2013): 14-23.

Ahl, Helene. The Scientific Reproduction of Gender Inequality: A Discourse Analysis of Research Texts on Women's Entrepreneurship. Libor: Copenhagen Business School, 2004.

Ahl, Helene, and Susan Marlow. "Exploring the Dynamics of Gender, Feminism and Entrepreneurship: Advancing Debate to Escape a Dead End?" Organization 19, no. 5 (2012): 543-562. 
Batliwala, Srilatha. Empowerment of Women in South Asia: Concepts and Practices. Mumbai: Asian-South Pacific Bureau of Adult Education, 1993.

Batliwala, Srialtha. "Taking the Power out of Empowerment: An Experiential Account." Development in Practice 17, no. 4/5 (2007): 557-565.

Beşpınar, F. Umut. "Questioning Agency and Empowerment: Women's WorkRelated Strategies and Social Class in Urban Turkey." Women's Studies International Forum 33, no. 6 (2010): 523-532.

Bruni, Attila, Silvia Gherardi, and Barbara Poggio. "Doing Gender, Doing Entrepreneurship: An Ethnographic Account of Intertwined Practices." Gender, Work and Organization 11, no. 4 (2004): 406-429.

Bulbeck, Chilla. "Feminist Theory in the Developing World: A Critique." Development Bulletin 26 (1993): 7-10.

Cindoğlu, Dilek, and Şule Toktaş. "Empowerment and Resistance Strategies of Working Women in Turkey." European Journal of Women's Studies 9, no. 1 (2002): 31-48.

Connell, Robert W. "Masculinities and Globalization." Men and Masculinities 1, no. 1 (1998): 3-23.

Cornwall, Andrea. “Women's Empowerment: What Works?” Journal of International Development 28, no. 3 (2016): 342-359.

Demir, Ömer, Mustafa Acar, and Metin Toprak. "Anatolian Tigers or Islamic Capital: Prospects and Challenges.” Middle Eastern Studies 40, no. 6 (2004): 166-188.

Filiztekin, Alpay, and İnsan Tunalı. “Anatolian Tigers: Are They for Real?” New Perspectives on Turkey 20 (1999): 77-106.

Giazitzoglu, Andreas, and Simon Down. "Performing Entrepreneurial Masculinities: An Ethnographic Account.” International Small Business Journal 35, no. 1 (2017): 40-60.

Gündüz-Hoşgör, Ayşe, and Jeroen Smits. "Variation in Labor Market Participation of Married Women in Turkey." Women's Studies International Forum 31, no. 2 (2008): 104-117.

Güneş-Ayata, Ayşe, and Gökten Doğangün. "Gender Politics of the AKP: Restoration of a Religio-Conservative Gender Climate." Journal of Balkan and Near Eastern Studies 19, no. 6 (2017): 610-627.

Gürbilek, Nurdan. The New Cultural Climate in Turkey. Living in a Shop Window. Translated by Victoria Holbrooke. London: Zed Books, 2011.

Hamilton, Eleanor. "The Discourse of Entrepreneurial Masculinities (and Femininities)." Entrepreneurship \& Regional Development 25, no. 1-2 (2013): 90-99.

Kabeer, Naila. "Resources, Agency, Achievements: Reflections on the Measurement of Women's Empowerment.” Development and Change 30 (2002): 435-464.

Kabeer, Naila. "Gender Equality and Women's Empowerment: A Critical Analysis of the Third Millennium Development Goal." Gender and Development 13, no. 1 (2005): 13-24.

Kandiyoti, Deniz. "Bargaining with Patriarchy.” Gender \& Society 2, no. 3 (1988): 274-290.

Kandiyoti, Deniz. "Locating the Politics of Gender: Patriarchy, Neo-Liberal Governance and Violence in Turkey." Research and Policy on Turkey 1, no. 2 (2016): 103-118.

Molyneux, Maxine. “Mobilization without Emancipation? Women's Interests, the State, and Revolution in Nicaragua." Feminist Studies 11, no. 2 (1985): 227-254.

Rowlands, Jo. "Empowerment Examined." Development in Practice 5, no. 2 (1995): 101-107. 
Rowlands, Jo. Questioning Empowerment: Working with Women in Honduras. Oxford: Oxfam, 1997.

Scheyvens, Regina. “Subtle Strategies for Women's Empowerment.” Third World Planning Review 20, no. 3 (1998): 235-253.

Sirman, Nükhet. "Feminism in Turkey: A Short History." New Perspectives on Turkey 3, no. 1 (1989): 1-34.

Stromquist, Nelly. "The Theoretical and Practical Bases for Empowerment." In Women, Education and Empowerment: Pathways Towards Autonomy, edited by C. Medel-Anonuevo, 13-22. Hamburg: UNESCO Institute for Education, 1995. UIE Studies 5. 